\title{
EFL oral skills behaviour when implementing blended learning in a content-subject teachers' professional development course
}

\section{Comportamiento de habilidades orales en inglés al implementar aprendizaje híbrido en un curso de desarrollo profesional para docentes de áreas de contenido}

\author{
Natalia Sánchez-Narváez ${ }^{1}$ \\ Sergio Alberto Chavarro-Vargas ${ }^{2}$
}

\author{
Citation/ Para citar este Artículo: Sánchez N. E Chavarro S. (2017). EFL Oral Skills Behavior when Implementing Blended Learning in a Content-Subject \\ Teachers' Professional Development Course. Colomb. Appl. Linguist. J., 19(2), pp. 263-276. \\ Received: 03-Oct-2017 / Accepted: 27-May-2017 \\ DOI: http://dx.doi.org/10.14483/calj.v19n2.10987
}

\begin{abstract}
The increasing use of technology in educational settings (Murray, 2014; Zandi, Thang, \& Krish, 2014) encourages teachers to refocus their professional development by centering their efforts on becoming proficient in the use of information and communication technologies (ICTs) in language lessons (Chen, Chen, \& Tsai, 2009). As such, this qualitative action research project intended to describe content-subject teachers' EFL oral behavior when blended learning was implemented in a professional development course and to determine the influence of blended learning in EFL oral skill behavior. The participants were seven content-subject teachers from a private school in Huila, Colombia. Data were gathered via in-depth interviews, class observations, video recording analysis, teachers' reflection, students' artifacts, and a survey. Data were collected during the implementation of an English blended course in which 12 lessons were divided into six face-to-face sessions and six online meetings. The findings suggest that EFL oral skill behavior is connected with use of vocabulary, use of body language, pronunciation and intonation patterns, production of chunks of language, monitoring oral production and, motivation and engagement. In addition, blended learning influenced participants' oral production.
\end{abstract}

Keywords: blended learning, content-subject teachers3, EFL oral skills, professional development.

\section{Resumen}

El uso creciente de la tecnología en escenarios educativos (Murray, 2014; Zandi, Thang, \& Krish, 2014) anima a los maestros a replantear su desarrollo profesional al enfocar sus esfuerzos para ser eficientes en el uso de las tecnologías de información y comunicación (TIC) en clases de inglés (Chen, Chen, \& Tsai, 2009). De acuerdo con las ideas previas, este proyecto cualitativo de investigación-acción buscaba describir el comportamiento de las

1 Universidad Surcolombiana, Neiva, Colombia. nataliasanchez1202@gmail.com

2 Universidad Surcolombiana, Neiva, Colombia. chavarrosergio@hotmail.com

3 Teachers who teach content subject in the mother tongue 
habilidades orales en inglés como lengua extranjera mientras se implementaba el enfoque de aprendizaje híbrido en un curso de desarrollo profesional docente; además pretende determinar la influencia del aprendizaje híbrido en el comportamiento de habilidades orales en inglés. Los participantes fueron siete docentes de áreas de contenido de una institución educativa privada en el departamento del Huila, Colombia. Los datos fueron recolectados a través de entrevistas a profundidad, observaciones de clase, análisis de video-grabaciones, reflexiones del profesor, productos de los estudiantes y una encuesta. Los datos fueron recolectados durante la implementación de un curso de inglés con enfoque de aprendizaje híbrido en el cual doce lecciones fueron divididas en seis sesiones presenciales y seis sesiones en línea. Los hallazgos sugieren que el comportamiento de las habilidades orales en ingles está conectado con uso de vocabulario, uso de lenguaje corporal, patrones de pronunciación y entonación, producción de segmentos de lenguaje, monitoreo de la producción oral y motivación. También, el aprendizaje híbrido influyó positivamente en la producción oral de los participantes.

Palabras clave: aprendizaje híbrido, desarrollo profesional, docentes de áreas de contenido, habilidades orales en inglés.

\section{Introduction}

In 2005, the Colombian Ministry of Education presented the National Bilingualism Program with the aim of helping Colombian citizens become bilingual by 2019 (Ministerio de Educación Nacional, 2005). Nevertheless, Colombia is facing limitations related to overcrowded classrooms, lack of resources, insufficient time exposure to the target language in class, low level of EFL proficiency held by primary and secondary English teachers, adoption of foreign educational models, poor infrastructure, and exclusion of indigenous native languages (Cárdenas E Miranda, 2014; Guerrero, 2008). This study responds to the national policies exploring contentsubject teachers' (CSTs) EFL oral skills behavior in a blended learning (BL) professional development course.

The contexts in which teachers develop their practices are continuously changing; therefore, it is essential to strengthen professional development (PD). In this sense, PD should be an ongoing process so that educators are up to date (Zandi et al, 2014). It seems clear that the world is constantly changing and this becomes a challenge for teachers' job. Although Colombian Education Policies consider English language learning as a mandatory subject (Ministerio de Educación Nacional, 2005), there exist limited opportunities to promote the development of oral skills in CSTs who are consistently asked to include English into cross-curricular projects as part of the school program. However, occasions for teachers to practice and interact in EFL with peers are rather poor (Taillefer $\mathcal{E}$ Munoz-Luna, 2013). Even though education and technology are working hand in hand in new teaching tendencies, teachers lack the knowledge and skills regarding the use of technological resources (Zandi et al, 2014). A needs analysis aimed at identifying researchable problems from a community visit was conducted at Einstein school ${ }^{4}$. For this purpose, an initial survey was applied to 35 teachers from the school. Based on the information gathered from the survey, the CSTs from Einstein School suggested that they had a low level of English proficiency. Interestingly, the educational goal of Einstein School is to become bilingual in the following ten years. This is evidenced in the educational project of the school (Proyecto Educativo Institucional; PEI) which gives an account on how the school will eventually begin a process of internationalization. However, the PEI of the school does not offer specific information regarding how CSTs will be supported to acquire communicative skills in EFL.

Einstein School provides CSTs with technological resources that can eventually work as tools to promote CSTs' use of EFL oral skills. This project took into consideration these resources to design a solid proposal for a teacher development course. It is important to highlight that this study has the purpose of exploring existent CSTs' EFL oral skills, which differs from the idea of developing 4 Pseudonyms have been used to protect the identity of the
participants. 
those skills. A blended learning approach allowed the combination of online and face-to-face (F2F) sessions to observe and give an account of how EFL oral skills were used by a group of CSTs of the school. Six CSTs participated in the study. Teachers' areas of specialization were Spanish, social studies, math, chemistry, arts, and music. Consequently, the following two research questions were formulated:

- What occurs to CSTs' EFL oral skills when implementing blended learning in a professional development course?

- What is the influence of blended learning on CSTS' EFL oral production in a professional development course?

- We continue by discussing the main theoretical tenets that work as a basis for the development of the research study. In addition, we explain methodological aspects such as the description of the participants and the main contents of the pedagogical intervention. Finally, we present findings, our conclusions, and pedagogical implications.

\section{Theoretical Framework}

\section{EFL Oral Skills}

For most people, the ability to speak a language is synonymous with knowing the target language since speech is the most basic means of human communication (Lazarton, 2001). In this sense, communication involves enabling someone else to understand what we want to tell them, which is often referred to as our message. Not only facts are communicated, but opinions and emotions are also transmitted in everyday situations (Lynch, 1996). Following Lynch's perspective, aside from communicating ideas, feelings, and emotions to others orally, humans negotiate ideas and transfer views on life to the rest of the world through spoken language. Brown (2007) establishes two types of spoken language: interpersonal or interactional and transactional. The former has to do with a chat in which one person offers a topic for comment by the other person. It is characterized by constantly shifting topics and a great deal of agreement on them. The latest happens when the purpose of the producer of the message is to convey information
(Brown \& Yule 1983). Furthermore, in the classroom there are two kinds of interaction: teacher-learner, or learner-learner interaction. These dynamics enhance not only the learners' opportunities to speak, but also help reduce the psychological border of public performance (Lynch, 1996).

There are three main reasons to encourage EFL students to speak in the classroom. First, students are provided with rehearsal opportunities. Second, oral practice offers feedback to teachers and learners. In other words, while interacting, instant corrections can be made in the conversation. Third, speaking practice helps learners become automatic users of various elements of language such expressions, codes, grammar structures, and phonics among others (Harmer, 2007).

In addition to Brown's (2007) perspective, the speaking strategies that learners may use to succeed in a speaking task have to do with asking for clarification, asking someone to repeat something, using fillers in order to get time to shape their thoughts or ideas before speaking, using conversation maintenance cues, getting someone's attention, using paraphrases, appealing for assistance from the interlocutor, using formulaic expressions, and using mind and nonverbal expressions to convey meaning.

Brown (2007) points out eight factors that determine the difficultness of speaking. These include: (1) clustering in which speech is phrasal; not word by word; (2) redundancy, or the over-use of words to clarify meaning; (3) reduced forms, or the use of contractions, elisions, and reduced vowels; (4) performance variables which are related to hesitations, pauses, backtracking, and corrections; (5) colloquial language in which learners relate words with idioms and phrases; (6) rate of delivery which helps learners to achieve an acceptable speed along with other attributes of fluency; (7) stress, rhythm, and intonation which are the most important characteristics of pronunciation used to convey meaning; and (8) interaction, or the creativity of conversational negotiation. With the previous factors in mind, a teacher can start planning lessons carefully based on the difficulty of the task. 
Furthermore, Brown (2007) asserts that there exist principles for teaching speaking listed as: focusing on fluency and accuracy, providing intrinsically motivating techniques, encouraging the use of authentic language in meaningful contexts, providing appropriate feedback and correction, linking speaking and listening, giving opportunities for oral communication, and encouraging the development of speaking strategies.

\section{Blended learning and Computer-Mediated Communication}

According to Sharma and Barret (2007), blended learning $(\mathrm{BL})$ is a strategy to overcome difficulties when interacting with technology. This concept refers to a course which combines a faceto-face classroom component with an appropriate use of technology (Sharma $\&$ Barret, 2007). By implementing $\mathrm{BL}$ in a language course for $\mathrm{a}$ pedagogical purpose, value to the teaching is added owing to the fact that the opportunities to practice EFL are extended outside the classroom where EFL instruction has traditionally taken place. Although the concept of BL is rather new, it has been applied in various areas of teaching. The methodology that blended teaching follows is divided into face-to-face tasks and virtual activities. As Bersin (2004) states, BL creates a favorable educational program for a specific audience by means of a wide variety of training media (Internet mediated activities and face to face encounters).

Sharma (2010) also expresses that when aiming to develop a BL course, it is relevant to consider the appropriateness of each strategy of course delivery and its relationship with the type of learning activity. Moreover, the author highlights the importance of both delivery modes, due to the fact that in face-to-face interaction, students develop fluency throughout in-class interaction and in online practice critical thinking skills are enhanced (Sharma, 2010). However, according to the author, learners tend to favor one of the two modes based on their technological or discursive skills.

To support the role of BL, Blake (2008) offers a review of computer-mediated communication (CMC) following two perspectives. The first perspective relates to synchronous computermediated communication (SCMC) and the second to asynchronous computer-mediated communication (ACMC). Payne (2004, as cited in Blake, 2008) points out some benefits of written SCMC. First, written messages exchanged are posted on the screen so that students are able to access and continue processing. Second, extra time allows students' linguistic processing which leads to organize their own contributions. Finally, students' affective filters are lower in SCMC because no one is looking over their shoulder as is the case in face-toface exchanges.

Additionally, a BL approach can be beneficial for adults or professionals in diverse areas as time can be managed in order to improve and grow in the area of knowledge with no constraints. Moreover, a sense of autonomy and self-reflection can be enhanced by combining face-to-face and online interaction with peers.

\section{Professional Development}

As Richards and Farrell (2005) point out, development is not linked directly with improving a specific job, but in the necessity of growth in any aspect of life. In the case of educators, professional development (PD) serves as a longer-term goal and seeks to facilitate teachers' understanding of teaching and of themselves as professionals. This essentially requires studying the diverse dimensions of an educator's teaching practices with the goal of improvement and can be seen as a continuous process. Similarly, following the author's ideas, one of the strategies school can implement is to provide the means by which teachers can acquire the knowledge and skills they need.

Moreover, one of the main reasons to pursue PD is to empower educators. In other words, thanks to PD teachers are able to become involved, cooperatively control, and have an impact on events and institutions that influence their lives (Murray, 2010). As Murray (2010) indicates, being an effective teacher requires professional knowledge, specialized skills, and also relates to teachers' personal experiences and qualities. It is also relevant to remark that PD is essential, especially in today's 
world of constantly changing technology (Murray, 2010). In fact, the idea of educating teachers with the purpose of responding to the current world demands is an idea that should be considered by any teacher and school director across the world.

\section{Content-Subject Teachers}

After reviewing the literature in depth, it might be claimed that a clear definition of content-subject teacher (CSTs) does not exist. However, for the purpose of this study we define CSTs as content teachers in charge of teaching a specific subject at school. The math teacher, the science teacher, and the geography teacher are examples of CSTs who have been educated in terms of pedagogy to teach content regarding a specific area of knowledge. However, their source of knowledge is strictly content-based and pedagogical within a specific field. They have not been exposed to formal EFL instruction.

\section{Methodology}

This qualitative action research study aimed to identify what occurs to content-subject teachers' EFL oral skills when implementing $\mathrm{BL}$ in a professional development course by following the spiral self-reflective cycle proposed by Kemmis and McTaggard (1998). Creswell (2013) presents a series of characteristics that encapsulate the perspectives of this approach. First, we collected research data in a setting where participants experienced the problem. We (researchers) are key instruments for data collection due to the great variety of qualitative driven data presented during the interventions. Qualitative research is also interpretive, allowing the researchers to see the problem from different theoretical lenses (Creswell, 2013).

\section{Participants}

The participants involved in this investigation were six CSTs from a private school in a small town in Huila, Colombia. This school is recognized for having the subject of English as one of the most relevant of its curriculum. Students have an average of thirteen hours of English instruction per week.
Additionally, one of the aspects in the vision of the school is to become bilingual in the following 10 years. There are 36 teachers at school, yet only 11 teachers have formal training in the English language. Taking into account the definition given for content-subject teachers, all six participants were instructed in a specific subject. The teachers who participated in this study were in charge of teaching content subjects such as math, science, ICT, arts, the Spanish language, and social studies in their mother tongue, Spanish. As the school organized teachers into subject groups, one specific teacher was selected to be the head teacher of each subjectrelated group. This leader was chosen to be the participant because of the opportunities they had to become disseminators of the knowledge they had built during the teacher development experience among the rest of the teachers.

In terms of demographic distribution, two teachers had been working in the school for five years and the other four participants for no more than a year. At the time of the investigation, four teachers were in charge of teaching a specific subject at both primary and secondary levels and two of them were only enrolled at the secondary level. Teachers devoted an average of 15 hours per week teaching their specific subject. In order to maintain ethical research practices, all participants were consented prior to data collection and were anonymized using the codes P1 through P6.

\section{Instruments and Data Collection Procedures}

We divided the data collection process into three main stages. First, in order to determine participants' initial perceptions regarding the project, each participant undertook a Likert scale survey and in-depth interview (see Appendix 1). After analyzing the ideas participants expressed in regards to the project and having a clear perspective of teachers' background knowledge in terms of language and technology proficiency, we developed the second stage as described below.

In order to focus the topics on the theory of language learning, we co-constructed a notionalfunctional syllabus among researchers and 
participants. Bearing in mind that the starting point for a notional-functional syllabus is the communicative purpose and conceptual meaning of language (Rabbini, 2002), six language functions were part of the pedagogical design: asking and providing personal information, expressing likes and dislikes about food, talking about school routines, expressing abilities, and describing people and asking for /giving directions. In the next step, following the principles of action research, planning, observation, and reflection (Richards \& Farrell, 2005), the main objective was to identify participants' attitudes and use of EFL oral skills during twelve interventions. The following stages of the process enabled the researchers to gather the data required for further analysis.

First, we established the roles of the two researchers. The objective of one researcher was to work as the instructor and to complete field notes as a source of data. Additionally, the second researcher observed the lessons and completed additional field notes. Observation operated as a powerful tool to identify information related to the categories previously established in the description of the behavior of EFL oral skills (Brown, 2007). Accordingly, observations followed a structured manner (Brown \& Rodgers, 2002) in which we determined prior categories related to EFL oral skills (use of body language, use of known structures, pronunciation, interaction, among others; Brown, 2007) as a guide for the observation process.

Second, we carried out a qualitative interview (Warren, 2002) at the end of the interventions. We interviewed all participants at the beginning and at the end of the research process. The role of the second researcher was to meet the participants individually at scheduled hours and record the interviews. In those interviews, participants talked about the perceptions they had in regards to the online and face-to-face sessions. The questions asked by the investigator followed the same categories used in the field notes and the observation formats.

The third stage occurred during the twelve interventions. The instruments used in this section were videotaped recordings and the transcripts obtained from each session. The main purpose of transcription was to identify specific situations in which
EFL oral skills were promoted among participants. In that sense, twelve sessions were videotaped and transcribed, six face-to-face and six online sessions. We devoted from one and a half to two hours per session, and there were two sessions weekly.

We used ATLAS.ti as an instrument in the process of analyzing data. ATLAS.ti belongs to the genre of qualitative data analysis software which supports qualitative data analysis (Friese, 2014). By using ATLAS.ti, it becomes much easier to systematically analyze data and to ask questions that without a digital mechanism would result time consuming (Friese, 2014). Seven main categories arose after data was uploaded and classified by the researchers in different emerging categories: Use of body language, pronunciation, use of vocabulary, production of chunks of language, monitoring oral production, motivation and engagement, influence of BL on EFL oral production. ATLAS.ti offers a well-structured set of mind maps that allowed the researchers to present the information collected in a more organized technique.

\section{Findings}

We took into consideration elements of grounded theory (Glaser $\&$ Strauss, 1967) to analyze data. We used coding as a technique to group common patterns and organize them into emerging categories. In fact, coding is here understood as a method of qualitative data analysis that can also be used independently from the grounded theory approach in whose context it was developed (Gläser $\mathcal{E}$ Laudel, 2013). We present the data analysis based on the emerging categories that support the research questions of this investigation. First, we elaborate on the behavior of oral skills during the implementation of the pedagogical intervention. Then, we analyze the influence of BL in CSTs' EFL oral production.

\section{Oral Skill behavior}

After completing a systematic analysis of the five sources of data, five categories emerged including: body language, use of vocabulary, pronunciation and intonation patterns, motivation and engagement, 
productions of chunks of language and monitoring oral production. Accordingly, these categories are related to the micro-skills for speaking proposed by Brown (2007).

Pronunciation. In regards to the category of pronunciation and intonation patterns, seven open codes emerged: spelling a word, recognizing differences in pronunciation, modeling pronunciation, mispronunciation, correcting pronunciation, clarifying pronunciation patterns and asking for pronunciation.

Spelling a word to model pronunciation. This indicates how participants used word spelling as a strategy to correct or to improve pronunciation patterns. This can be perceived in the following example.

Instructor: How do you spell it? [referring to the word HAMILTON]. So, she starts spelling her last name in this case Hamilton. So, can we start spelling her name? It is possible to do it?

P4: H-a-m-i-I-t-o-n

Instructor: Excellent, h-a-m-i-I-t-o-n

[Participants repeat the letters]

(Transcript 1.1-01-09-2015-F2F)

In this example, the instructor wants to check for understanding. Then, the participant P4 provides the spelling of the word. This interaction helped the learner to associate meaning with pronunciation and to recall previous knowledge about the pronunciation of the alphabet. Repetition contributed to reinforce the sounds and the organization of the letters in a word. Moreover, P4 empowers herself to some extent that she is able to assume the role of instructor. Henceforth, P4 becomes a pronunciation model that the rest of the class follows. This resembles Saville-Troike's (2006) argument, as she claims that:

Speaker pronunciation is also a factor that influences listener comprehension. Many learners report that they find it easier to understand L2 utterances produced by speakers of their own L1 than by native speakers of the L2, presumably because the speakers' accent is closer to their own phonological perceptual system. (p. 161)
Mispronunciation, asking for pronunciation and clarifying pronunciation patterns. This is an example of how learners asked for pronunciation and the form in which they were supported by their peers in class.

P4: My name is Rose

Instructor: What is your surname or your last

name?

P4: Williams

Instructor: Exactly.

P4: How do you pronounce this word: / su:rmam/?

P2: /şneIm/

(Transcript 1.1-01-09-2015-F2F)

The word surname is mispronounced by $\mathrm{P} 4$ who follows patterns of L1 to pronounce the word in English. In reply, P2 mentioned the correct pronunciation of the word surname and focuses on clarifying pronunciation patterns emphasizing the accent of the word. The behavior evidenced is a clear example of collaboration in class to support others' learning. Such clarification and asking for repetition are part of the speaking strategies that learners may use to succeed in a speaking task (Brown, 2007).

The following excerpt exemplifies the moments in which the participants tried to respond to direct questions.

P5: /uai mu:vl ju: uan si:/. ¿Qué película te volverías a ver? ¿Está bien o no?

Instructor: Yes, like, what movie would you watch again?

Native Speaker: Oh yes, I have one that in Spanish is "las ventajas de ser invisible."

Instructor: Cande, did you understand the answer?

P5: No, no much.

(Transcript-1.2-02-09-2015-Online Session)

Participant P5 mispronounces a sentence affecting the message she tries to transfer; however, after the instructor's feedback, the participant is able to make herself understood. Mispronunciation leads the participant to take risks at speaking and she starts to overcome difficulties associated with feeling afraid of using the target language. Lynch's 
(1999) perspective resembles the previous example. Speaking can cover a wide range of oral activities from genuine interaction (i.e., actually talking to someone about something) to repetition drills. In the classroom, there are two kinds of interaction: teacher-learner, or learner-learner interaction. The teacher's role has to do with arranging specific spaces in the classroom to let the leaners negotiate meaning through speaking tasks. These tasks could be performed individually or in small groups. These dynamics enhance not only the learners' opportunities to speak, but these also help reduce the psychological border of public performance (Lynch, 1996).

\section{Recognizing differences in pronunciation.}

\author{
Instructor: Ok, in this exercise you learned \\ how to identify different directions. What was the \\ first clue? \\ P1: To go to the psychologist. \\ Instructor: Well, to go to the office. And the \\ second? \\ P4: Ir a la oficina principal. (Go to the principal's \\ office) \\ P1: No era oficina principal. Era la oficina del \\ principal. Es decir la del rector. Y decía además \\ lo que se hacía allá o sea lavarse los dientes, las \\ manos y qué era next to the principal's office. \\ (Transcript-6.1-F2F-06-10-15)
}

The instructor asks for information about the clues provided to find specific locations at school. P4 associates principal's office with the main office or an important office at the school. After hearing this interpretation, P1 disagrees and claims that the principal's office is the place where the school principal is. Following the previous ideas, the participants engaged in the conversations recognized the differences in terms of pronunciation of a word in English with an equivalent word in Spanish in terms of spelling. Despite the similar spelling, the pronunciation and the meaning of the word principal changed from one language to the other. This may be evidenced in Brown (2007) when affirming that there exist factors that determine the difficulty of speaking. From the author's perspective, stress, rhythm, and intonation are the most important characteristics of pronunciation used to convey meaning.
Correcting pronunciation. Participants offered feedback when they listened to a word or known expression incorrectly pronounced.

P3: Library /li:brari/

P1: No, es /laibrari/ [emphasizing the correct pronunciation]

(Transcript-6.1-F2F-06.10.15)

In this case, P3 pronounces the word library following L1 pronunciation patterns. Eagerly, P1 corrects his classmate uttering the correct pronunciation. As stated by Saville-Troike's (2006), cross-linguistic influence occurs in all levels of IL: vocabulary, pronunciation, grammar, and all other aspects of language structure and use. Focusing on fluency and accuracy, and to providing appropriate feedback and correction are common suggestions to teach, practice, and learn how to speak in EFL (Brown, 2007).

Body language. We indicate the use of facial expressions and body language after examining the data collected.

\begin{abstract}
Use of facial expressions and body language to convey meaning.

Face to face: The participants used their body in order to make themselves understood. Teacher also used this strategy to clarify concepts. When they did not understand a word, participants showed doubt in their face. Most of them did not know how to ask for clarification; for that reason, they used body language, such as hands and face movements.

Online: it was a little bit difficult to identify the body gestures of the participants in this session. However, during the dialogue with the guest, most of them used their hands to show shapes and numbers and also some of them answered questions by moving their heads to say yes or no.
\end{abstract}

(Class Observation-1.1-F2F-01.09.15)

Regarding the face-to-face sessions, the data suggests that participants' use of facial expressions and body language was significant. Participants were able to express doubt with facial expressions. This fact encouraged peers to paraphrase or repeat 
chunks of language with the purpose of making the message be understood. When a word was not transferred, participants used body movements and gestures to mimic and communicate the intended message. In this sense, it seems clear that communication involves enabling someone else to understand what we want to tell them. Not only facts are communicated, but we transmit opinions and emotions (Lynch, 1996). When it comes to virtual sessions, participants tended to use gestures and mimicry with the purpose of communicating unknown words or expressions in the L2. Doubt, agreement, and disagreement were also communicated using facial expressions. Body movements were not often used, as it seemed to be difficult to capture these movements with an ordinary webcam.

Use of vocabulary. The open codes we grouped to consolidate this subcategory are asking for new vocabulary, asking for word construction, internalizing vocabulary, providing new vocabulary, introducing new vocabulary and use of new vocabulary.

Asking and providing new vocabulary. The following example will illustrate the open code abovementioned.

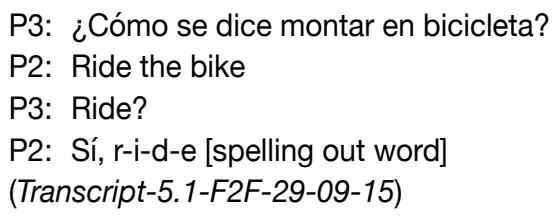

P3: ¿Cómo se dice montar en bicicleta?

P2: Ride the bike

P3: Ride?

P2: Sí, r-i-d-e [spelling out word]

(Transcript-5.1-F2F-29-09-15)

In this case, P3 resorts to the L1 with the purpose of asking for unknown vocabulary. As a result, P2 who carefully listens to the inquiry, reports comprehension using the L2 and providing the target vocabulary. Having the requested vocabulary, P3 is able to report comprehension and participate in class using the L2. Following Brown (2007), interaction can be recognized and highlighted in terms of the creativity of speakers to carry out conversational negotiation. This is an example of collaboration among learners to interact in L2.

Asking for word construction and use of known vocabulary.

\author{
P4: /sti:m/ (unknown word) es Delgado? s-t-i-m \\ [spelling out word] \\ P2: No, slim s-l-i-m [spelling out word] \\ (Transcript-5.1-F2F-29-09-15)
}

P4 bears certain doubts about the meaning of the word slim. Then, P4 asks for correction mentioning that /sti:m/ means thin. P2 provides feedback and claims that "stim" is not correct, instead the person should use the word "thin" that better addresses the meaning described by the visual aid shown. P2's reply is a clear example of using known vocabulary with communicative purposes. Covering a good range of topics in a course ensures that a wide range of vocabulary is used. Having this in mind, Nation and Newton's (2009) ideas can be addressed in order to assure that certain topics included in class may facilitate learners' use of background knowledge.

Production of chunks of language. The following paragraph focuses on production of chunks of language. From Brown's (2007) perspective, production of chunks of language involves the use of short and simple sentences or phrases commonly used in EFL that enhances communication in L2. The open codes that support this category were: use of known chunks of language to ask for information, provide information and report comprehension, reflecting upon grammatical issues

Use of known chunks of language to ask for information, provide information, and report comprehension.

Instructor: Here you have information about address.

P2: My address is, ah juemadre no sé

P4: How do you say Carrera?

P5: ¿Esa Carrera es Street?

Instructor: Is street and avenue.

P3: ¡Venga Nata 5 ayúdeme a traducir esto!

P2: My address is street....

P4: ¿Esa es la misma avenida? Calle, street, avenida, avenue.

(Transcript 1.1-F2F-01-09-2015)

5 All names are pseudonyms to protect the identity of the participants. 
In this case, P2 resorts to the L1 to show surprise using the words iAh juemadre, I don't know! Similarly, P4 makes use of a chunk of language in the L2 to ask for specific information about a word in the L1 needed to construct and communicate meaning. In response, P5 hesitates while claiming that carrera is street and asks the instructor for information to clarify. P2 takes risks and starts to construct a sentence to provide information about the location of her house. Participants kept repeating the initial sentences and they eventually added more words. Finally, P4 made associations between the L1 and L2. This resembles Lynch's assumptions as she claims that speaking can cover a wide range of oral activities from genuine interaction (i.e., actually talking to someone about something) to repetition drills.

Monitoring oral production. Participants constantly resorted to L1 to ask the instructor or classmates for clarification. This facilitated comprehension and enhanced communication in L2. Besides, long periods of silence were perceived while participants were interacting using L2. The use of hesitation devices such as, "eh," "ahm," "ehm," "mmm" among others implemented to process input or prepare a suitable chunk of language to communicate a message. The following excerpt better illustrates.

Instructor: Yes, and also you will write a short description about you.

P1: Cuando voy a describir y a usar adjetivos, ¿hay un orden para yo decir, long, brown, wavy...?

Instructor: Sí, tiene un orden pero en este momento vamos a hacerlo largo, forma y color. Ok vamos a trabajar.

[Long period of silence, instructor checks the excercise]

P1: Para hablar de altura puedo decir tall or short?

P2: O médium height.

P3: ¿Cómo se dice montar en bicicleta?

P2: Ride the bike.

P3: Ride?

P1: Sí, r-i-d-e [spelling out word]

(Transcript-5.1-F2F-29-09-15)
As shown in the previous extract, there exists a close relationship between the L1 and L2 in which participants constantly use English and Spanish to enhance communication and convey meaning (Brown, 2007).

Motivation and engagement. CSTs' motivation and engagement was evident in the data examined. This is illustrated as follows.

P5: Me! Go straight ahead, in the first corner turn left and the museum is next to the library. Instructor: Excellent! Now the last one to the Italian restaurant.

P3: Yo, yo sé. Go straight ahead, past green street, turn left eh... ¿Cómo es esquina?

P1: Corner

P3: Ahh, turn left in the corner, and the restaurant is...

P2: Next to...

P3: Thanks, next to the cinema.

[15 turns omitted]

P3/P2: $\quad$ Ah! Ganamos... (We won!)

P1: The winners.

P2: No, genial, pero corrí mucho. (It was great, but I ran too much)

[11 turns omitted]

All: Thank you teacher.

P3: Muy bueno todo. (Everything was very good!)

P1: Deberían hacer estas clases todo el año, así practicamos más el idioma y no se nos olvida. (These lessons should be taught during the whole year, so that we can practice and we do not forget anything)

(Transcript-6.1-F2F-06-10-15)

P5 is motivated to participate in class, so she volunteers to provide instructions about how to arrive at the library. The sentence produced by P5 was correct and was easy for the other classmates to understand. Consequently, P3 also eagerly volunteered to provide instructions about how to find the Italian restaurant. Furthermore, P3 resorted to the L1 to ask for unknown vocabulary. Therefore, P1 reports comprehension and provides the vocabulary needed in the L2 which helps P3 complete her speech and successfully accomplish 
the task. Moreover, P3 and P2 eagerly say we won! This means they enjoyed the activity and for them the task can be compared to a competition to learn English. Finally, P1 claims that those kinds of EFL activities should be carried out every day, so that they may practice EFL and they would not forget anything. Accordingly, Lynch (1996) points out that interactional activities can be performed individually or in groups to enhance not only speaking but selfconfidence in EFL learning.

\section{Influence of BL in EFL Oral Production}

After analyzing data, we found out two emerging sub-categories: BL creates opportunities to reinforce acquired EFL; and Skype ${ }^{\circledR}$ as a powerful tool to enhance online EFL interaction.

BL creates opportunities to reinforce acquired EFL. We combined media with traditional EFL activities with the purpose of creating an optimum professional development program for the CSTs who participated in this study (Bersin, 2004).

Positive and negative aspects of the lesson Face to face: Most of the participants were really committed to completing the activities; also, there were some teachers that thanked us for applying those activities that helped them to forget the school issues that sometimes seemed to be stressful. However, there were too many things to do in the school due to the end of the term. So, most of the teachers finished the activity early to have some time to complete their duties.

Online: Students were on time for the interview because they selected the time to do it. The topics covered during the course helped a lot for the final task. It was also touching to hear from the students their gratitude for the classes. Besides the time constrains and the variety of school duties, this course as they asserted helped them to go back to the high school and to understand the role of the students in the classroom. The technological tools used despite the technical problems were easy to handle and to use.

(Class Observation 6.1\&6.2/06-10-15)
Participants acknowledged the significant role the pedagogical intervention using blended learning had played in their EFL learning. The pedagogical intervention not only served as a strategy to teach EFL, but helped participants share their understandings with colleagues through learning and talking about different aspects of the school. Moreover, participants and observers agreed on the fact that despite certain difficulties emerged at the beginning with technology, little by little and by helping each other, those difficulties improved. Virtual scenarios helped the learners gain more engagement because that learning can take place without a physical setting and certainly the online class can be effective as virtual place to disseminate, collect, and exchange knowledge and ideas (Bender, 2003).

Skype ${ }^{\circledR}$ as a powerful tool to enhance online EFL interaction. Skype ${ }^{\circledR}$ worked as a bridge to connect the participants (Taillefer $\mathcal{E}$ Munoz-Luna, 2013) so that they were able to share ideas and practice EFL.

Instructor: ¿Cómo ha sido tu experiencia en la interacción vía Skype con tu profesor, tus compañeros y el hablante nativo?

(How was your experience interacting with teachers, classmates and the foreigner speaker?) P5: Ha sido muy enriquecedora a nivel personal. Todo ha sido muy chévere, o sea absolutamente toda la disposición, la creatividad que tienen ustedes en el manejo de las sesiones presenciales. Entonces practicamos en el Skype lo que aprendimos en clase. Sí. Ahí (sesiones en línea) la cuestión es tiempo. A veces se llena uno de cosas y realmente entonces uno no puede asistir, pero ahí es donde está la cuestión, que uno se pierde si no asiste con juicio.

(In my opinion, it has been very fruitful. It all has been great, it means, willingness and creativity that you have had during face-to-face lessons. Then, we practiced in Skype ${ }^{\circledR}$ what we learnt in class. Yes. There (online sessions) the deal is time. Sometimes, you have many things to do and you are not able to attend. But, that's the deal, you get lost if you do not attend diligently) (Interview-002-P5-06.10.15) 
In the previous excerpt, P5 highlights the importance of attending both face-to-face and online sessions. In this sense, SCMC offered more time for linguistic processing in order to prepare learners' own contributions. In addition, students' affective filters are lower in SCMC because no one is looking over their shoulder as is the case in face-toface exchanges (Payne, 2004, cited in Blake, 2008). P5 needs to follow the connection established between what is taught in face-to-face lessons and the practice offered through virtual meetings. From her viewpoint, it is necessary to be motivated and devote time to online sessions. This resembles Neumeier's (2005) perception as:

Blended learning seeks to generate a coherent and harmonious balance between online access to knowledge and face-to-face human interaction by taking into account learners' and teachers' aptitudes and attitudes. (p. 165)

\section{Conclusions}

The findings obtained from this investigation suggest that EFL oral skill behavior was associated with the use of body language, vocabulary, pronunciation and intonation patterns, productions of chunks of language, monitoring oral production, and motivation. Consequently, blended learning creates opportunities to reinforce acquired EFL. Furthermore, data analysis suggested that Skype was seen as a powerful tool to establish connections between participants so they would be able to practice their $\mathrm{L} 2$ beyond physical interaction.

We categorized EFL oral skill behavior in the following way: the first category was pronunciation and intonation patters. Aspects such as asking for pronunciation, spelling a word to model pronunciation, and asking for clarification in terms of pronunciation were evident among the face-toface and virtual interactions. These features are part of the strategies that Brown (2007) presents which learners used in order to succeed in a speaking task. Body language emerged as a strategy learners use to convey meaning when facing conversations in the L2 (Brown, 2007). Additionally, use of vocabulary was evident in the oral interactions when participants asked for new vocabulary or word construction, and they used that new vocabulary in a speaking task. In this sense, creativity of the speakers was fundamental to carry out conversational negotiation (Brown, 2007). Therefore, during the interventions, participants tended to provide information using known or new chunks of language. This could be perceived in students' artifacts and through the sessions when participants used automatized rulebased systems and memory-based chunks that helped learners communicate (Skehan, 1998, as cited in Saville-Troike, 2006). In addition, during the production of chunks of language, participants monitored oral production using strategies such as backtracking, hesitation, and resorting to the L1 as well as peer correction as a tool to ask for and provide clarification. In this sense, as Harmer (2007) points out, students are provided with rehearsal and feedback opportunities and they can become automatic users of various elements of language. Finally, motivation and eagerness to participate in both face-to-face and online sessions were perceived in data analysis.

\section{Implications of the Study}

Today's world demands teachers from different subjects to demonstrate command of the English language enabling them to communicate in real life situations. Teachers require being educated on how to use available ICT resources in order to improve teaching skills and practices (Chen et al., 2009). Accordingly, we strongly believe that the teachers' role can be transformed if programs of teacher education and PD are carried out. In this sense, a blended learning approach may be implemented in a PD to transform traditional conceptions of EFL teaching allowing learning to occur inside (F2F) and outside (online) the language classroom (Bersin, 2004).

We found that there was not a clear definition for the population selected for this study due to the fact that previous research in the field of professional development has not associated CSTs and EFL oral skills. From our perspective, it is essential to research how CSTs and schools can eventually benefit from implementing professional development programs that involve EFL learning. This may probably trace a clearer path towards bilingualism. Finally, we recommended further research exploring how 
CSTs can benefit from involvement in professional development programs focused on CLIL.

\section{References}

Bender, T. (2003). Discussion-based online teaching to enhance student learning. Sterling, VA: Stylus Publishing.

Bersin, J. (2004). The blended learning book: Best practices, proven methodologies and lessons learned. San Francisco, CA: Pfeiffer.

Blake, R. J. (2008). Brave new digital classroom: Technology and foreign language learning. Washington, DC: Georgetown University Press.

Brown, D. (2007). Teaching by principles: An interactive approach to language pedagogy. New York, NY: Pearson Longman.

Brown, J. D., \& Rodgers, T. S. (2002). Doing second language research: An introduction to the theory and practice of second language research for graduatel master's students in TESOL and applied linguistics, and others. Oxford: Oxford University Press

Brown, G., E Yule, G. (1983). Teaching the spoken language (vol. 2). Cambridge, UK: Cambridge University Press.

Cárdenas, R., \& Miranda, N. (2014). Implementation of the National Bilingual Program in Colombia: An interim assessment. Educación y Educadores, 17(1), 51-67.

Chen, Y., Chen, N. S., E Tsai, C. C. (2009). The use of online synchronous discussion for web-based professional development for teachers. Computers $\mathcal{E}$ Education, 53(4), 1155-1166.

Creswell, J. W. (2013). Research design: Qualitative, quantitative, and mixed methods approaches. London: Sage Publications.

Friese, S. (2014). Qualitative data analysis with ATLAS. $t i$. London: Sage.

Gläser, J., E Laudel, G. (2013). Life with and without coding: Two methods for early-stage data. Forum: Qualitative Social Research, 14(2), Art 5.

Glaser, B. G., E Strauss, A. L. (1967). The discovery of grounded theory: Strategies for qualitative theory. New Brunswick: Aldine Transaction.

Guerreo, C. (2008). Bilingual Colombia: What does it mean to be bilingual within the framework of the national plan of bilingualism? Colombian Applied Linguistics Journal, 10, 27-45.
Harmer, J. (2007). How to teach English. Harlow: Pearson Longman.

Kemmis, S., \& McTaggart, R. (Eds.). 1988. The action research planner. Victoria, Australia: Deakin University Press

Lazaraton, A. (2001). Teaching oral skills. In M. CelceMurcia (Ed.), Teaching English as a foreign language (pp. 103-104). Boston: Heinle, Cengage Learning.

Lynch, T. (1996). Communication in the language classroom. Oxford: Oxford University Press.

Ministerio de Educación Nacional. (2006). Serie Guías 22. Estándares básicos de competencias en lenguas extranjeras: inglés. Formar en lenguas extranjeras: iEl reto! Lo que necesitamos saber y saber hacer. Bogotá: Ministerio de Educación Nacional.

Murray, A. (2010). Empowering teachers through professional development. English Teaching Forum, 48(1), 1-11.

Nation, I. S., \& Newton, J. (2009). Teaching ESL/EFL listening and speaking. New York, NY: Routledge, Taylor E Francis.

Neumeier, P. (2005). A closer look at blended learning: Parameters for designing a blended learning environment for language teaching and learning. ReCALL, 17(2), 163-178.

Rabbini, R. (2002). An introduction to syllabus design and evaluation. The Internet TESL Journal, (VIII)5, 1-6.

Richards, J., \& Farrell, T. (2005). Professional development for language teachers: Strategies for language learning. Cambridge: Cambridge Language Education.

Saville-Troike, M. (2006). Introducing second language acquisition. New York: Cambridge University Press.

Sharma, P. (2010). Blended learning. ELT journal, 64(4), 456-458.

Sharma, P., E Barret, B. (2007). Blended learning: Using technology in and beyond the language classroom. Oxford: MacMillan Education.

Taillefer, L., \& Munoz-Luna, R. (2013). Developing oral skills through Skype ${ }^{\circledR}$ : A language project analysis. Procedia-Social and Behavioral Sciences, 141, 260264.

Warren, C. (2002). Qualitative interviewing. In J. Gubrium E J. Holstein (Eds.), Handbook of interview research (pp. 83-103). London: SAGE.

Zandi, P., Thang, S., E Krish, P. (2014). Teacher professional development through blogging: Some preliminary findings. Procedia-Social and Behavioral Sciences, $118,530-536$ 


\section{Appendix 1}

\section{Interview Protocol}

I. Saludo inicial y presentación del objetivo de la entrevista.

II. Desarrollo:

a. Producción de oraciones

1. ¿Cómo crees que las sesiones presenciales han contribuido en tu habilidad para producir oraciones en inglés?

2. ¿Crees que los materiales impresos te permiten construir oraciones para comunicarte oralmente?

3. ¿cómo crees que las sesiones virtuales a través de Skype han influido en la producción de oraciones en inglés?

b. Uso adecuado de palabras

4. ¿El vocabulario que se provee en las sesiones presenciales es útil para desenvolverse en una situación comunicativa?

5. ¿Cómo puedes describir tu aprendizaje del vocabulario expuesto en clase?

6. ¿De qué forma las actividades que se comparten a través de la plataforma virtual de Edmodo refuerzan el vocabulario que se presenta en las sesiones presenciales?

7. ¿cómo crees que la práctica oral a través de las sesiones virtuales a través de Skype fortalecen el uso de vocabulario en situaciones reales de comunicación?

c. Implementación de estrateglas lingüisticas para dar claridad al mensaje

8. ¿Cuándo hablas haces uso de pausas, muletillas, te corriges a ti mismo y repites para enmendar algún error que cometas? ¿Cuál es la que más empleas?

9. ¿De qué manera el uso de estas estrategias lingüísticas favorece el desarrollo de tu habilidad oral?

10. ¿De qué manera la interacción a través de Skype ha permitido que mis compañeros provean retroalimentación a través de mi discurso?

\section{d. Uso de estructuras gramaticales}

11. ¿Explica cómo las estructuras gramaticales que se presentan en las sesiones presenciales pueden ser pertinentes para construir y organizar los mensajes que usted transmite?

12. ¿De qué forma los ejercicios prácticos que son posteados en Edmodo contribuyen a reforzar tu competencia gramatical?

e. Pronunciación y entonación

13. ¿Crees que los ejercicios ofrecidos en clase ayudan a fortalecer tu pronunciación en inglés? ¿Por qué?

14. ¿Qué otro tipo de ejercicios crees que deberian ser incorporados para perfeccionar tu pronunciación en inglés?

15. ¿De qué modo consideras que la entonación influye en el desarrollo de situaciones comunicativas diversas?

16. ¿Cómo ha sido tu experiencia en la interacción vía Skype con tu profesor, tus compañeros y el hablante nativo?

f. Uso de lenguaje corporal para expresar significados

17. ¿Haces uso de lenguaje corporal para reforzar el menaje que buscas transmitir? ¿Ha funcionado esta estrategia?

18. ¿Cómo calificarias la interacción que se lleva a cabo mediante las video llamadas en Skype?

III. Final de la Entrevista

19. ¿Qué es lo que más te ha gustado de las sesiones virtuales?

20. ¿Qué es lo que menos te ha gustado de las sesiones virtuales?

21. ¿Qué es lo que más te ha gustado de las sesiones presenciales?

22. ¿Qué es lo que menos te ha gustado de las sesiones presenciales?

23. ¿Qué tipo de actividades te gustaría que se agregaran en las sesiones presenciales?

24. ¿Qué tipo de actividades te gustaría que se agregaran en las sesiones virtuales?

25. ¿Hay algo que no te haya preguntado y que deberia haberlo hecho?

26. ¿Hay algo que quieras añadir?

IV. Agradecimiento y despedida

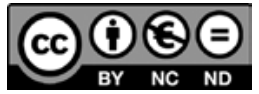

